Génét. Sél. Evol., 1986, 18 (2), 185-212

\title{
Estimated genetic trends for growth and carcass traits in two French pig breeds
}

\author{
Michèle TIXIER (1) and P. SELLIER \\ I.N.R.A., Station de Génétique quantitative et appliquée, \\ Centre de Recherches zootechniques, $F 78350$ Jouy-en-Josas
}

\section{Summary}

Genetic trends for growth and carcass traits were estimated in the Large White (LW) and French Landrace (FL) pig breeds, using the records of 7529 LW and 4118 FL gilts reared in progeny-test stations between 1970 and 1981, and 34887 LW and 16779 FL boars reared in performance-test stations between 1969 and 1981.

Three methods of estimation were used. Method 1 was the within-sire regression of progeny's performance on time, taking into account the selection of sires on sons' records in the boar performance-test data set. Sires and dams were grouped into cohorts according to year of birth, and the cohort effects were estimated either by a fixed linear model (method 2) or by a mixed linear model (method 3). Differences between sire and dam trends were seldom significant. Method 2 under-estimated the genetic gain when sires or dams were being selected on the records of their offspring on test. The results of methods 1 and 3 being pooled, the estimated annual genetic trends were $2.9 \pm 0.8$ (LW) and $1.0 \pm 1.0$ (FL) for average daily gain (ADG, g) in the boar performance-test (B.T.), data set $-4.7 \pm 2.1$ (LW) and $3.2 \pm 2.7$ (FL) for ADG in the progeny-test (P.T.) data set, $-0.011 \pm 0.002$ (LW) and $-0.008 \pm 0.003$ (FL) for food conversion ratio (FCR, $\mathrm{kg}$ feed $/ \mathrm{kg}$ gain) in the B.T. data set, $-0.003 \pm 0.007$ (LW) and $-0.022 \pm 0.008$ (FL) for FCR in the P.T. data set, $-0.26 \pm 0.02(\mathrm{LW})$ and $-0.16 \pm 0.02$ (FL) for average backfat thickness (mm) in the B.T. data set, $0.42 \pm 0.07(\mathrm{LW})$ and $0.15 \pm 0.10$ (FL) for percentage lean in the P.T. data set. Carcass length increased as a correlated response to selection, whereas meat quality traits did not deteriorate. The main feature of this study, i.e. the higher yearly response in carcass traits (around 1 p. 100 of the mean) than in growth traits (around 0.3 p. 100 of the mean), is discussed.

Key words : Pig, genetic trend, growth, carcass, mixed model.

\section{Résumé}

Evolutions génétiques des performances de croissance et de carcasse estimées dans deux races porcines françaises

Les évolutions génétiques des performances de croissance et de carcasse ont été estimées chez le Large White (LW) et le Landrace Français (LF), en utilisant les données

(1) Permanent address : I.N.R.A., Laboratoire de Génétique factorielle, F 78350 Jouy-en-Josas. 
recueillies de 1970 à 1981 dans les stations de contrôle de descendance (C.D.) sur 7529 femelles LW et 4118 femelles LF et les données recueillies de 1969 à 1981 dans les stations de contrôle individuel (C.I.) sur 34887 verrats LW et 16779 verrats LF.

Trois méthodes d'estimation des évolutions génétiques ont été utilisées. La première méthode a été la régression intra-père des performances des descendants sur le temps, en tenant compte de la sélection des pères sur les performances de leurs fils en station de contrôle individuel. Les pères et les mères ont été regroupés en cohortes en fonction de leur année de naissance. Les effets "cohorte» ont été estimés par un modèle linéaire fixé (méthode 2) ou mixte (méthode 3). Les évolutions estimées chez les pères et les mères diffèrent rarement de façon significative. Les résultats de la méthode 2 sont sous-estimés lorsque les pères ou les mères sont sélectionnés sur les performances de leurs descendants en station. Les résultats des méthodes 1 et 3 ayant été combinés, les estimées des évolutions génétiques annuelles ont été $2,9 \pm 0,8(\mathrm{LW})$ et $1,0 \pm 1,0(\mathrm{LF})$ pour le gain moyen quotidien (GMQ, g) en C.I., - 4,7 $\pm 2,1$ (LW) et $3,2 \pm 2,7$ (LF) pour le GMQ en C.D., $-0,011 \pm 0,002$ (LW) et $-0,008 \pm 0,003$ (LF) pour l'indice de consommation (IC en $\mathrm{kg}$ d'aliment / $\mathrm{kg}$ de gain) en C.I., $-0,003 \pm 0,007$ (LW) et $-0,022 \pm 0,008$ (LF) pour l'IC en C.D., - $-0,26 \pm 0,02$ (LW) et $-0,16 \pm 0,02$ (LF) pour l'épaisseur moyenne de lard dorsal (en mm) en C.I., $0,42 \pm 0,07$ (LW) et $0,15 \pm 0,10$ (LF) pour le pourcentage de muscle en C.D. La longueur de carcasse a augmenté en réponse à la sélection et l'évolution génétique de la qualité de la viande n'a pas été défavorable.

Le fait que le progrès génétique annuel soit plus élevé pour les caractères de carcasse (autour de 1 p. 100 de la moyenne) que pour les caractères de croissance (autour de 0,3 p. 100 de la moyenne) est discuté.

Mots clés : Porc, progrès génétique, croissance, carcasse, modèle mixte.

\section{Introduction}

Selection for growth and carcass traits of the pig started in France about 30 years ago. Progeny-test stations opened in 1953, then the performance-testing of boars in central stations was set up in 1966. In addition, « on farm» testing has taken place since 1970 .

There is evidence from examining the trends of yearly means for the traits measured in progeny-test and boar performance-test stations that phenotypic improvement has occurred in growth rate and feed efficiency as well as in body composition. The change in performance observed in the testing stations represents both the genetic progress and the environmental change. Without any planned design to measure genetic gain, special statistical techniques have to be used to bring the genetic component out of the phenotypic trend. This was done in France for the Large White breed, first by OLLIVIER (1974) analysing progeny-test data recorded from 1953 to 1966, then by Naveau (1971) and Chesnais (1973) analysing boar performance-test data recorded from 1966 to 1970 . Later on, Houix et al. (1978) could use an experimental line selected for litter size as a control line to estimate genetic change for growth and carcass traits in the Large White breed from 1965 to 1973. Since the latter study, no accurate information was available on genetic change in the French pig breeds.

The purpose of this investigation was to estimate the genetic change actually achieved for slaughter pig traits in the 2 breeds, i.e. Large White and French Landrace, which were represented by the largest numbers of animals in central testing stations. 


\section{Material and methods}

\section{A. Data}

Data used were (1) data collected in boar performance-test stations from 1969 to 1981 , and (2) data collected in progeny-test stations from 1970 to 1981 . The periods chosen for the 2 types of stations correspond to minimal changes in testing procedures. The 2 data sets were analysed separately.

\section{Records from boar performance-test stations (B.T. data)}

Testing procedure was applied to discontinuous batches. A batch was defined by the year of test (13 levels), the testing station (13 levels) and the 2-week period of entering into the station (about 4 levels for each year $\times$ station combination).

The weights at the beginning and the end of test were initially 30 and $80 \mathrm{kgs}$ in 1969 but were respectively changed to 35 and $85 \mathrm{kgs}$ in 1971 , then final weight was set to $90 \mathrm{kgs}$ in 1977 . Young boars were individually fed on a liberal feeding scale based on the voluntary intake of the animal during 2 daily meals of 20 minutes each. Backfat thickness being measured at two different weights flanking the intended final weight, adjusted records were obtained by interpolation. Three ultrasonic measurements were taken on each side of the spine, $4 \mathrm{~cm}$ from the mid-dorsal line, at the levels of the shoulder, the last rib and the hip joint, respectively.

The coefficients used between 1970 and 1980 in the 3-trait selection index of boars were 0.1 for average daily gain (g), -20 for food conversion ratio $(\mathrm{kg} \mathrm{feed} / \mathrm{kg}$ gain) and -7 for average backfat thickness ( $\mathrm{mm}$ ).

The structure of the data analysed is presented in table 1. The Large White breed was represented by twice as many records as the French Landrace breed. Sires and dams were grouped into cohorts according to their year of birth. There were on average 2.8 dams per sire in each breed and 6.9 boars tested per sire.

TABLE 1

Structure of the data collected from 1969 to 1981 in boar performance-test stations and used for analysis.

\begin{tabular}{|c|c|c|c|c|}
\hline Breed & Larg & e White & French & Landrace \\
\hline No. of animals $\ldots .$. & 34887 & & 16779 & \\
\hline $\begin{array}{l}\text { No. of cohorts of : (a) } \\
- \text { sires (first-last year of birth) } \ldots \ldots \ldots \\
- \text { dams (first-last year of birth) } \ldots \ldots \ldots\end{array}$ & $\begin{array}{l}15 \\
17\end{array}$ & $\begin{array}{l}(1966-1980) \\
(1964-1980)\end{array}$ & $\begin{array}{l}14 \\
15\end{array}$ & $\begin{array}{l}(1967-1980) \\
(1966-1980)\end{array}$ \\
\hline $\begin{array}{l}\text { Average no. of offspring by cohort of : } \\
\text { - sires (range) } \ldots \ldots \ldots \ldots \ldots \ldots \ldots \ldots \ldots \ldots \ldots \ldots \ldots\end{array}$ & $\begin{array}{l}2326 \\
2052\end{array}$ & $\begin{array}{r}(587-3277) \\
(76-3176)\end{array}$ & $\begin{array}{l}1199 \\
1119\end{array}$ & $\begin{array}{l}(58-1957) \\
(41-1835)\end{array}$ \\
\hline $\begin{array}{l}\text { Average no. of sires by paternal cohort } \\
\text { (range) } \ldots \ldots \ldots \ldots \ldots \ldots \ldots \ldots \ldots \ldots\end{array}$ & 346 & $(69-492)$ & 169 & $(19-303)$ \\
\hline Average no. of dams by maternal cohort & 834 & & 451 & \\
\hline
\end{tabular}

(a) A cohort is a set of sires (or dams) born in the same year. Note that the first few cohorts which were represented by less than 20 offspring were excluded from the analyses. 
The overlapping between cohorts and years of test (tabl. 2) shows a clustering of the data toward the diagonal. Most records for a sire cohort (n) occurred in the years $(n+1),(n+2)$ and $(n+3)$, whereas this distribution reached the year $(n+4)$ for the dam cohorts. A sire cohort (n) was mostly represented by offspring from 4 dam cohorts, i.e. $(n-2)$ to $(n+1)$.

TABLE 2

Illustration of the overlapping between years of test and parental cohorts in the data from boar performance-test stations in the Large White breed (partial representation).

\begin{tabular}{|c|c|c|c|c|c|c|c|c|c|c|c|}
\hline \multirow{2}{*}{$\begin{array}{l}\text { Year } \\
\text { of test }\end{array}$} & \multirow{2}{*}{$\begin{array}{l}\text { Sire } \\
\text { cohort }\end{array}$} & \multicolumn{10}{|c|}{ Dam cohort } \\
\hline & & 1968 & 1969 & 1970 & 1971 & 1972 & 1973 & 1974 & 1975 & 1976 & 1977 \\
\hline \multirow{6}{*}{$\begin{array}{c}1975 \\
\text { (3404 pigs) }\end{array}$} & 1970 & 0 & 0 & 2 & 0 & 1 & 4 & 0 & 0 & 0 & 0 \\
\hline & 1971 & 0 & 2 & 10 & 32 & 21 & 18 & 6 & 0 & 0 & 0 \\
\hline & 1972 & 1 & 2 & 16 & 86 & 183 & 163 & 31 & 0 & 0 & 0 \\
\hline & 1973 & 0 & 13 & 51 & 177 & 485 & 998 & 328 & 3 & 0 & 0 \\
\hline & 1974 & 0 & 0 & 9 & 25 & 94 & 219 & 416 & 1 & 0 & 0 \\
\hline & 1975 & 0 & 2 & 0 & 0 & 0 & 3 & 3 & 1 & 0 & 0 \\
\hline \multirow{6}{*}{$\begin{array}{c}1976 \\
\text { (3015 pigs) }\end{array}$} & 1971 & 0 & 0 & 0 & 0 & 0 & 0 & 2 & 1 & 0 & 0 \\
\hline & 1972 & 0 & 0 & 0 & 1 & 30 & 15 & 18 & 5 & 0 & 0 \\
\hline & 1973 & 0 & 7 & 2 & 11 & 45 & 157 & 200 & 39 & 0 & 0 \\
\hline & 1974 & 0 & 0 & 11 & 27 & 105 & 309 & 699 & 256 & 1 & 0 \\
\hline & 1975 & 1 & 1 & 1 & 11 & 40 & 100 & 332 & 585 & 0 & 0 \\
\hline & 1976 & 0 & i) & 0 & 0 & 0 & 0 & 2 & 1 & 0 & 0 \\
\hline \multirow{7}{*}{$\begin{array}{c}1977 \\
\text { (3405 pigs) }\end{array}$} & 1970 & 0 & 0 & 4 & 0 & 0 & 0 & 0 & 0 & 0 & 0 \\
\hline & 1971 & 0 & ()) & 0 & 0 & 0 & 0 & 0 & 0 & 0 & 0 \\
\hline & 1972 & 0 & 0 & 0 & 0 & 2 & 1 & 5 & 15 & 0 & 0 \\
\hline & 1973 & 0 & ( & 0 & 0 & 2 & 22 & 20 & 17 & 14 & 0 \\
\hline & 1974 & 0 & 0 & 0 & 7 & 20 & 65 & 124 & 139 & 17 & 0 \\
\hline & 1975 & 0 & 0 & 0 & 5 & 51 & 104 & 349 & 742 & 299 & 2 \\
\hline & 1976 & 0 & 0 & 1 & 6 & 5 & 27 & 182 & 453 & 703 & 2 \\
\hline
\end{tabular}

\section{Records from progeny-test stations (P.T. data)}

Groups of 2 litter sisters are sent by breeding herds, before they reach the weight of $30 \mathrm{kgs}$. Initially, 4 groups born from unrelated sows had to be tested to give a breeding index to the sires. Since 1975, records were also used to evaluate herds' genetic levels. Consequently, the average number of gilts sired by the same boar has been decreasing.

The piglets belonging to the same test batch entered the station within a period of 2 weeks. The test batch was defined as previously for the B.T. data. The test period started when the average weight of the group reached $35 \mathrm{kgs}$. Each full-sib group was kept together in one pen and was fed ad libitum on a pen basis. Only complete full-sib groups were considered for feed efficiency analysis. Pigs were slaughtered during the week in which they reached an average liveweight of $100 \mathrm{kgs}$. Standardized 
cutting of one half-carcass was performed, as described by OLLIVIER (1970). Lean content of the carcass with head (EEC reference) was estimated from the relative weights of five joints expressed as percentages of the weight of half-carcass, according to the following prediction equation established by Pommeret \& Naveau (1979) :

p. 100 lean $=-0.75+80$ (p. 100 ham) +106 (p. 100 loin) +48 (p. 100 belly) -50 (p. 100 backfat) -66 (p. 100 leaf fat).

Three measurements of meat quality were taken on the ham on the day after slaughter, namely :

- ultimate $\mathrm{pH}\left(\mathrm{pH}_{\mathrm{u}}\right)$ of Adductor femoris ;

- imbibition time (Imb), assessing water holding capacity of meat and defined as the time (in tenths of seconds) necessary for a $\mathrm{pH}$ paper to get wet when put on the freshly cut surface of Biceps femoris;

- reflectance (Ref) of Gluteus superficialis (scale 0-1000).

The analysis dealt with the following meat quality index (MQI), established by JACQUET $e$ t al. (1984) as a predictor of the technological yield of Paris ham processing :

$$
\mathrm{MQI}=53.7+5.9019 \mathrm{pH}_{\mathrm{u}}+0.1734 \mathrm{Imb}-0.0092 \text { Ref. }
$$

The structure of the data used for analysis is presented in table 3. Sires and dams were grouped into cohorts as described for the previous data set. Dams were almost as numerous as full-sib groups, as very few sows were repeatedly used. There were on average 4.4 tested gilts and 2.1 dams per sire in both breeds. The overlapping between cohorts and years of test followed the same pattern as in the previous data set, with a tendency to a shorter period of use of the breeding animals. A sire cohort was mostly represented during 2 years of test, with offspring generally issued from 3 different dam cohorts.

TABLe 3

Structure of the data collected from 1970 to 1981 in progeny-test stations and used for analysis.

\begin{tabular}{|c|c|c|c|c|}
\hline Breed & & ge White & French & h Landrace \\
\hline $\begin{array}{l}\text { No. of animals : } \\
\text { - with average daily gain and body } \\
\text { composition records } \ldots \ldots \ldots \ldots \ldots \ldots\end{array}$ & 7529 & & 4118 & \\
\hline $\begin{array}{l}\text { No. of full-sib groups (food conversion } \\
\text { ratio analysis) } \ldots \ldots \ldots \ldots \ldots \ldots \ldots\end{array}$ & 3696 & & 2001 & \\
\hline $\begin{array}{l}\text { No. of cohorts of : } \\
\text { 一 sires (first-last year of birth) } \ldots \ldots \ldots \\
\text { - dams (first-last year of birth) } \ldots \ldots \ldots\end{array}$ & $\begin{array}{l}14 \\
15\end{array}$ & $\begin{array}{l}(1967-1980) \\
(1966-1980)\end{array}$ & $\begin{array}{l}13 \\
15\end{array}$ & $\begin{array}{l}(1968-1980) \\
(1966-1980)\end{array}$ \\
\hline $\begin{array}{l}\text { Average no. of } \text { offspring by cohort of }: \\
\text { - sires (range) } \\
\text { - dams (range) } \ldots \ldots \ldots \ldots \ldots \ldots \ldots \ldots \ldots \ldots \ldots \ldots\end{array}$ & $\begin{array}{l}538 \\
502\end{array}$ & $\begin{array}{l}(102-947) \\
(100-901)\end{array}$ & $\begin{array}{l}317 \\
275\end{array}$ & $\begin{array}{r}(178-482) \\
(28-471)\end{array}$ \\
\hline $\begin{array}{c}\text { Average no. of sires by paternal cohort } \\
\text { (range) } \ldots \ldots \ldots \ldots \ldots \ldots \ldots \ldots \ldots \ldots \ldots \ldots\end{array}$ & 129 & $(23-262)$ & 69 & $(28-133)$ \\
\hline Average no. of dams by maternal cohort ... & 240 & & 129 & \\
\hline
\end{tabular}




\section{B. Methods}

The methods used for the analysis of data were, on one hand, the within-sire regression of performance on time (SMITH, 1962) and, on the other hand, the estimation of sire and dam cohort effects by a linear model taking into account environmental effects. Breeds were treated separately.

\section{Within-sire regression of performance on time (SMITH, 1962)}

This method, called Smith's method in the following, was applied to the sires that had successive offspring on test during more than 6 months. These « repeated » sires represented only 15 p. 100 of all sires for each breed in P.T. data and 23 p. 100 in B.T. data. Performance of each offspring was expressed as a deviation from the batch average and denoted $\mathrm{D}$. The following model of linear regression was applied :

$$
D_{i j}=\mu+s_{i}+b T_{i j}+e_{i j}
$$

where $s_{i}$ is the fixed effect of the $i^{\text {th }}$ sire, sire effects being absorbed together with the constant $\mu$,

$T_{i j}$ is the 3-month-period during which the $j^{\text {th }}$ offspring of the $i^{\text {th }}$ sire entered the station,

$\mathrm{b}$ is the average within-sire regression coefficient of offspring's performance on the 3-month-period of entrance on test,

$\mathrm{e}_{\mathrm{ij}}$ is a random effect normally distributed $N\left(0, \sigma_{\mathrm{e}}^{2}\right)$.

The estimate of genetic trend per unit of time (i.e. 3-month-period) is $-2 b$, and the estimate of annual genetic trend, $\Delta \mathrm{G}_{\mathrm{a}}$, is therefore :

$$
\Delta \mathrm{G}_{\mathrm{a}}=-8 \mathrm{~b}
$$

However, equation (1) assumes no assortative matings and random sampling of repeated sires. As natural mating was mostly used in the selection herds, the oldest boars tended to be mated to the oldest sows. The regression coefficient $(x)$ of age of dam on age of sire had to be taken into account in order not to bias upwards the estimate of genetic trend. Equation (1) was modified as follows :

$$
\Delta \mathrm{Ga}=-8 \mathrm{~b} /(1+\mathrm{x})
$$

Equation (2) over-estimates the genetic trend if the repeated sires are selected on the results of their first tested progeny. A preliminary study showed that this was not the case in the P.T. data set, so equation (2) was used without change. On the other hand, sires that were represented for more than one year in the B.T. records appeared to have significantly better first progeny than average. Initial superiority of their offspring was, in the Large White breed, $6.4 \mathrm{~g}$ for average daily gain, $-0.018 \mathrm{~kg}$ feed $/ \mathrm{kg}$ gain for food conversion ratio and $-0.24 \mathrm{~mm}$ for average backfat thickness, whereas corresponding figures in the French Landrace breed were $4.9 \mathrm{~g},-0.015 \mathrm{~kg}$ feed $/ \mathrm{kg}$ gain and $-0.13 \mathrm{~mm}$.

While equation (2) could still be applied to the group of sires $\left(S_{1}\right)$ that were used for more than 6 months and less than 1 year, an approximate correction factor (f) had to be derived for the group of sires $\left(S_{2}\right)$ that were used for more than 1 year. The argument presented by SYRSTAD (1966) was followed as shown in appendix A. The equation used for the records of offspring from $S_{2}$ sires was :

$$
\Delta G_{a}=-2\left[2\left(b^{\prime}+f\right) /(1+x)\right]
$$


where $b^{\prime}$ is the average within-sire regression of offspring's performance on the 6-month-period of entrance on test.

The 2 estimates of annual genetic trend obtained from $S_{1}$ and $S_{2}$ sires were weighted by the reciprocal of their sampling variance to give a pooled estimate of $\Delta \mathrm{G}_{\mathrm{a}}$ for the B.T. data set.

This method gives only a linear description of genetic change, and estimates the genetic trend in the sire population.

\section{Estimation of parental cohort effects}

Estimation of sire and dam cohort effects does not assume a linear genetic trend and allows to distinguish the genetic change realized in sires and dams.

\section{a) Fixed linear model}

Individual records were first described by the following linear model :

$$
\mathbf{Y}_{\mathrm{ijkl}}=\mu+\mathrm{a}_{\mathrm{i}}+\mathrm{g}_{\mathrm{j}}+\mathrm{f}_{\mathrm{k}}+\mathrm{e}_{\mathrm{ijkl}}
$$

where $Y_{i j k l}=$ individual record precorrected for initial weight in growth traits or for final weight in carcass traits,

$a_{i}=$ fixed effect of the $i^{\text {th }}$ test batch (e.g. $i=1, \ldots, 728$ for B.T. data in the Large White breed),

$\mathrm{g}_{\mathrm{j}}=$ fixed effect of the $\mathrm{j}^{\text {th }}$ sire cohort (e.g. $\mathrm{j}=1, \ldots, 15$ for B.T. data in the Large White breed),

$\mathrm{f}_{\mathrm{k}}=$ fixed effect of the $\mathrm{k}^{\text {th }}$ dam cohort (e.g. $\mathrm{k}=1, \ldots, 17$ for B.T. data in the Large White breed),

$\mathrm{e}_{\mathrm{ijkl}}=$ random effect associated with the residual influence of each pig, normally distributed with expected value zero and variance $\sigma_{\mathrm{e}}^{2}$ tions.

Equations for $\ell$ and batch effects were absorbed to obtain the least-squares solu-

The batch was replaced by the day of slaughter within station for the analysis of the meat quality index.

Food conversion ratio was analyzed on a group basis, records being adjusted for the average initial weight of the 2 sisters. The constant estimates for cohort effects were obtained by setting to zero the first level of each effect, and they were plotted against the cohort number to obtain a graphic representation of the genetic trend in the population.

In order to compare the results with those of the first method and of previous studies, a covariance model was also applied to the data :

$$
Y_{i 1}=\mu+a_{i}+b_{1} G_{i 1}+b_{2} F_{i 1}+e_{i 1}
$$

where $a_{i}=$ fixed effect of the $i^{\text {th }}$ test batch, batch effects being absorbed together with $\mu$,

$b_{1}$ (resp. $b_{2}$ ) = linear regression coefficient on the year of birth $G$ of the sire (resp. on the year of birth $F$ of the dam) which represents half the genetic trend in sires (resp. in dams), $\mathrm{e}_{\mathrm{il}}=$ random effect normally distributed $N\left(0, \sigma_{\mathrm{e}}^{2}\right)$. 
Three estimates of annual genetic trend were derived from this analysis :

$$
\begin{aligned}
& \Delta \mathrm{G}_{\mathrm{a} 1}=2 \mathrm{~b}_{1} \text { in the population of sires, } \\
& \Delta \mathrm{G}_{\mathrm{a} 2}=2 \mathrm{~b}_{2} \text { in the population of dams, } \\
& \Delta \mathrm{G}_{\mathrm{a}}=\mathrm{b}_{1}+\mathrm{b}_{2} \text { in the whole population }
\end{aligned}
$$

These estimates might be biased if sires and dams were selected on their initial progeny. If, for a given year of test, older sires are the best of their cohort while young sires are a random sample, then the mean genetic value of the oldest cohort will be overestimated.

\section{b) Mixed linear model}

The sampling of sires and dams within the cohorts could be taken into account by using the mixed linear model methodology.

The procedure described by LUNDEHEIM \& ERIKSSON (1984) was followed. Individual records were adjusted for the initial or final weight and described by the following model :

$$
\mathrm{Y}_{\mathrm{ijklmn}}=\mu+\mathrm{a}_{\mathrm{i}}+\mathrm{g}_{\mathrm{j}}+\mathrm{s}_{\mathrm{j} 1}+\mathrm{f}_{\mathrm{k}}+\mathrm{d}_{\mathrm{k}(\mathrm{j} 1) \mathrm{m}}+\mathrm{e}_{\mathrm{ijk} \mathrm{lmn}}
$$

where $a_{i}=$ fixed effect of the $i^{\text {th }}$ test batch for P.T. data (e.g. $i=1, \ldots, 228$ for the Large White breed) or of the $\mathrm{i}^{\text {th }}$ year $\times$ station combination for B.T. data (e.g. $\mathrm{i}=1, \ldots, 151$ for the Large White breed),

$\mathrm{g}_{\mathrm{j}}=$ fixed effect of the $\mathrm{j}^{\text {th }}$ sire cohort,

$\mathrm{f}_{\mathrm{k}}=$ fixed effect of the $\mathrm{k}^{\text {th }}$ dam cohort,

$\mathrm{s}_{\mathrm{j} 1}=$ random effect associated with the additive genetic value of the $1^{\text {th }}$ sire in the $j^{\text {th }}$ cohort with expected value zero and variance $\sigma_{\mathrm{s}}^{2}$,

$\mathrm{d}_{\mathrm{k}(\mathrm{jl}) \mathrm{m}}=$ random effect associated with the additive genetic value of the $\mathrm{m}^{\text {th }}$ dam in the $\mathrm{k}^{\text {th }}$ cohort mated to the $\mathrm{jl}^{\text {th }}$ sire, with expected value zero and variance $\sigma_{\mathrm{d}}^{2}$,

$\mathrm{e}_{\mathrm{ijklmn}}=$ random effect associated with the residual influence of each pig, normally distributed with expected value zero and variance $\sigma_{\mathrm{e}}^{2}$.

Random effects of the model (6) were supposed to be independently distributed. The variance components used for the mixed model analysis were those previously estimated by Ollivier et al. (1981) for the P.T. data recorded from 1970 to 1978 (tabl. 4), and by Ollivier et al. (1980) for the B.T. data recorded from 1969 to 1978 (tabl. 5). The procedure of estimation was the following : individual records expressed as deviations from the batch average were analyzed with a random hierarchical model, where the effect of the sire could not be separated from that of the herd. It was assumed that genetic variances have remained constant in the population under selection between 1970 and 1980. There was no within-dam variance component for food conversion ratio, which is recorded on a group basis in P.T. data, and model (6) was modified to omit the effect of the dam for this particular trait.

Sires and dams were supposed to be unrelated. Nesting the dams within the sires led to treatment as different dams of the same sow successively mated to 
different boars. However, repeated use of the same sow did not occur in the P.T. data set and was a rare event in the B.T. data set. The dam and sire effects were absorbed into the fixed effects for computational feasibility (LUNDEHEIM \& ERIKSSON, 1984).

\section{TABLE 4}

Variance components used for the mixed model analysis of data from progeny-test stations (a).

\begin{tabular}{|c|c|c|c|c|}
\hline Trait & $\sigma_{\mathrm{s}}^{2}$ & $\sigma_{\mathrm{d}}^{2}$ & $\sigma_{\mathrm{e}}^{2}$ & $\mathrm{~h}^{2}$ \\
\hline Average daily gain $(g)$ & 500 & 3397 & 1099 & 0.40 \\
\hline $\begin{array}{c}\text { Food conversion ratio of full-sib } \\
\text { groups }(\mathrm{kg} \text { feed } / \mathrm{kg} \text { gain) }\end{array}$ & 0.0046 & \multicolumn{2}{|c|}{0.0410} & 0.40 \\
\hline Percentage lean (b) & 1.038 & 1.822 & 4.045 & 0.60 \\
\hline Carcass length $(\mathrm{cm})$ & 0.928 & 1.238 & 4.023 & 0.40 \\
\hline
\end{tabular}

(a) The 2 breeds were pooled for estimating sire $\left(\sigma_{s}^{2}\right)$, dam $\left(\sigma_{d}^{2}\right)$ and residual $\left(\sigma_{e}^{2}\right)$ variance components; $h^{2}$ is heritability.

(b) Variance components were derived from the variance and covariance components of the traits included in the equation of prediction of percentage lean.

\section{TABLE 5}

Variance components used for the mixed model analysis of data from boar performance-test stations.

\begin{tabular}{|c|c|c|c|c|c|c|c|c|}
\hline \multirow{2}{*}{ Trait } & \multicolumn{4}{|c|}{ Large White breed } & \multicolumn{4}{|c|}{ French Landrace breed } \\
\hline & $\sigma_{\mathrm{s}}^{2}$ & $\sigma_{\mathrm{d}}^{2}$ & $\sigma_{\mathrm{e}}^{2}$ & $\mathrm{~h}^{2}$ & $\sigma_{\mathrm{s}}^{2}$ & $\sigma_{\mathrm{d}}^{2}$ & $\sigma_{e}^{2}$ & $h^{2}$ \\
\hline $\begin{array}{r}\text { Average daily gain } \\
\text { (g) } \ldots \ldots \ldots \ldots \ldots\end{array}$ & 515 & 737 & 3436 & 0.44 & 333 & 725 & 3149 & 0.32 \\
\hline $\begin{array}{l}\text { Food conversion ra- } \\
\text { tio }(\mathrm{kg} \text { feed } / \mathrm{kg} \\
\text { gain) } \ldots \ldots \ldots \ldots\end{array}$ & 0.0032 & 0.0053 & 0.0295 & 0.34 & 0.0026 & 0.0056 & 0.0328 & 0.25 \\
\hline $\begin{array}{l}\text { Average backfat } \\
\text { thickness (mm) }\end{array}$ & 0.435 & 0.515 & 1.650 & 0.67 & 0.370 & 0.538 & 1.651 & 0.58 \\
\hline
\end{tabular}

The constant estimates for cohort effects were plotted against the cohort number and compared to those of the fixed model.

The yearly genetic trend was estimated from the linear regression of the estimates for sire cohort $(\hat{\mathrm{g}})$ and dam cohort $(\hat{\mathrm{f}})$ on the cohort number, excluding the estimate for the first cohort effect. Regression coefficients were doubled to estimate the annual genetic trends in sires on one hand, in dams on the other hand. The sum of both regression coefficients gave an estimate of the overall genetic trend. 
The variances and covariances between the estimates were taken into account by using a weighted regression, in order to obtain the standard error of the estimate of annual genetic trend (appendix B).

In order to evaluate to what extent the estimates of genetic trends derived from the mixed model analysis are affected by a change in the variance components used in the model, two values of heritability $(0.2$ and 0.6$)$ were assumed in addition to the «true» value for average daily gain of Large White B.T. data set.

Meat quality index could not be submitted to the mixed model analysis, owing to the very large number of levels for the effect of day of slaughter.

\section{Results}

Table 6 shows means and standard deviations of the traits. The 2 breeds show similar phenotypic variation for all traits. The standard deviations of average daily gain and food conversion ratio are of the same magnitude in P.T. and B.T. data sets. Table 6 gives an average standard deviation for each trait but the observed standard deviations could vary by a factor of 1 to 3 according to the station in B.T. data. In order to take into account this between-station heterogeneity in phenotypic variance, a preliminary analysis was performed using transformed data, obtained by dividing original records, expressed as deviations from the batch average, by the standard deviation of the corresponding station-year of test combination. As analysis of original or transformed data gave almost identical estimates of genetic trends with no appreciable change in accuracy (TIXIER, 1984), only the results obtained using untransformed data will be presented here.

TABLE 6

Means $(\bar{x})$ and standard deviations (SD) of the traits studied.

\begin{tabular}{|c|c|c|c|c|c|}
\hline \multirow{2}{*}{ Trait } & \multirow{2}{*}{$\begin{array}{l}\text { Data } \\
\text { set (a) }\end{array}$} & \multicolumn{2}{|c|}{ Large White breed } & \multicolumn{2}{|c|}{ French Landrace breed } \\
\hline & & $\overline{\mathbf{x}}$ & SD (b) & $\overline{\mathbf{x}}$ & SD (b) \\
\hline Average daily gain (g) & $\begin{array}{l}\text { B.T. } \\
\text { P.T. }\end{array}$ & $\begin{array}{l}859 \\
812\end{array}$ & $\begin{array}{l}83 \\
91\end{array}$ & $\begin{array}{l}836 \\
785\end{array}$ & $\begin{array}{l}78 \\
82\end{array}$ \\
\hline $\begin{array}{r}\text { Food conversion ratio }(\mathrm{kg} \text { feed } / \\
\mathrm{kg} \text { gain) } \ldots \ldots \ldots \ldots \ldots\end{array}$ & $\begin{array}{l}\text { B.T. } \\
\text { P.T. }\end{array}$ & $\begin{array}{l}2.71 \\
3.14\end{array}$ & $\begin{array}{c}0.24 \\
0.23 \text { (c) } \\
(0.24)^{(d)}\end{array}$ & $\begin{array}{l}2.80 \\
3.27\end{array}$ & $\begin{array}{c}0.24 \\
0.24 \text { (c) } \\
(0.25)^{(d)}\end{array}$ \\
\hline Average backfat thickness $(\mathrm{mm})$ & B.T. & 15.4 & 1.9 & 14.6 & 1.8 \\
\hline Percentage lean. & P.T. & 50.5 & 3.1 & 51.0 & 3.1 \\
\hline Carcass length $(\mathrm{cm})$ & P.T. & 100.2 & 2.7 & 101.7 & 2.7 \\
\hline Meat quality index (point) & P.T. & 85.6 & 2.9 & 85.3 & 3.2 \\
\hline
\end{tabular}

(a) B.T. = boar performance-test stations ; P.T. = progeny-test stations.

(b) Estimated on a within-batch basis.

(c) SD of the food conversion ratio of groups of 2 full-sibs.

(d) Estimated SD of the individual measurement, calculated by assuming that the phenotypic correlation between full-sibs is the same for food conversion ratio as for average daily gain. 


\section{A. Phenotypic trends}

Annual phenotypic trends are presented in table 7. They were significantly favourable, except for meat quality index which did not show any real change whatever the breed. Improvement was generally higher in the Large White than in the French Landrace breed, except for food conversion ratio in B.T. data and carcass length in P.T. data. It can be added that the phenotypic trends of average backfat thickness measured on carcass side in P.T. stations were similar to those found on average backfat thickness measured by ultra-sonics in B.T. stations : they were -0.47 and $-0.35 \mathrm{~mm} /$ year in the Large White and French Landrace breeds respectively. It is also worth noting that voluntary food intake increased phenotypically at an annual rate of $0.007 \mathrm{~kg} /$ day $(\mathrm{P}<0.001)$ for both breeds on the ad libitum feeding system used in P.T. stations.

TABLE 7

Annual phenotypic trends $( \pm \mathrm{SE})$ for growth and carcass traits from 1969 (B.T.) or 1970 (P.T.) to 1981.

\begin{tabular}{|c|c|c|c|c|c|c|c|}
\hline Trait & $\begin{array}{c}\text { Data } \\
\text { set }\end{array}$ & Large & White bre & eed & French & Landrace & breed \\
\hline Average daily gain $(\mathrm{g}) \ldots$ & $\begin{array}{l}\text { B.T. (a) } \\
\text { P.T. }\end{array}$ & $\begin{array}{l}9.4 \\
8.9\end{array}$ & $\begin{array}{l} \pm 0.1 \\
\pm 0.4\end{array}$ & $\begin{array}{l}* * * * \\
* * *\end{array}$ & $\begin{array}{l}7.6 \\
7.1\end{array}$ & $\begin{array}{l} \pm 0.2 \\
\pm 0.5\end{array}$ & $\begin{array}{l}* * * \\
* * *\end{array}$ \\
\hline $\begin{array}{c}\text { Food conversion ratio }(\mathrm{kg} \\
\mathrm{feed} / \mathrm{kg} \text { gain) }\end{array} \ldots \ldots \ldots$ & $\begin{array}{l}\text { B.T. (a) } \\
\text { P.T. }\end{array}$ & $\begin{array}{l}-0.032 \\
-0.027\end{array}$ & $\begin{array}{l}2 \pm 0.004 \\
7 \pm 0.001\end{array}$ & $* * *$ & $\begin{array}{l}-0.03 \\
-0.02\end{array}$ & $\begin{array}{l}39 \pm 0.001 \\
20 \pm 0.002\end{array}$ & $2 * * * *$ \\
\hline $\begin{array}{l}\text { Average backfat thickness } \\
(\mathrm{mm}) \ldots \ldots \ldots \ldots \ldots\end{array}$ & B.T. (a) & -0.45 & \pm 0.003 & $* * *$ & -0.37 & $7 \pm 0.005$ & $5 * * *$ \\
\hline Percentage lean & P.T. & 0.16 & \pm 0.01 & $* * *$ & 0.09 & $9 \pm 0.02$ & $* * *$ \\
\hline Carcass length $(\mathrm{cm})$ & P.T. & 0.33 & \pm 0.01 & $* * *$ & 0.38 & $8 \pm 0.02$ & **** \\
\hline Meat quality index (point) & P.T. & -0.02 & \pm 0.01 & NS & -0.02 & $2 \pm 0.02$ & NS \\
\hline
\end{tabular}

***: : P $<0.001 ;$ NS : $\mathrm{P}>0.10$.

(a) Changes in the initial and final weights of test period were taken into account for the analysis of B.T. data.

\section{B. Genetic trends}

Yearly genetic trends are presented in table 8 for the 3 methods of estimation.

\section{Growth traits}

a) Boar performance-test data

Annual genetic trends for the growth traits measured in B.T. stations were significantly favourable according to the mixed model analysis and to SMITH's method. In the French Landrace breed, genetic change appeared rather low since 1972 in both 


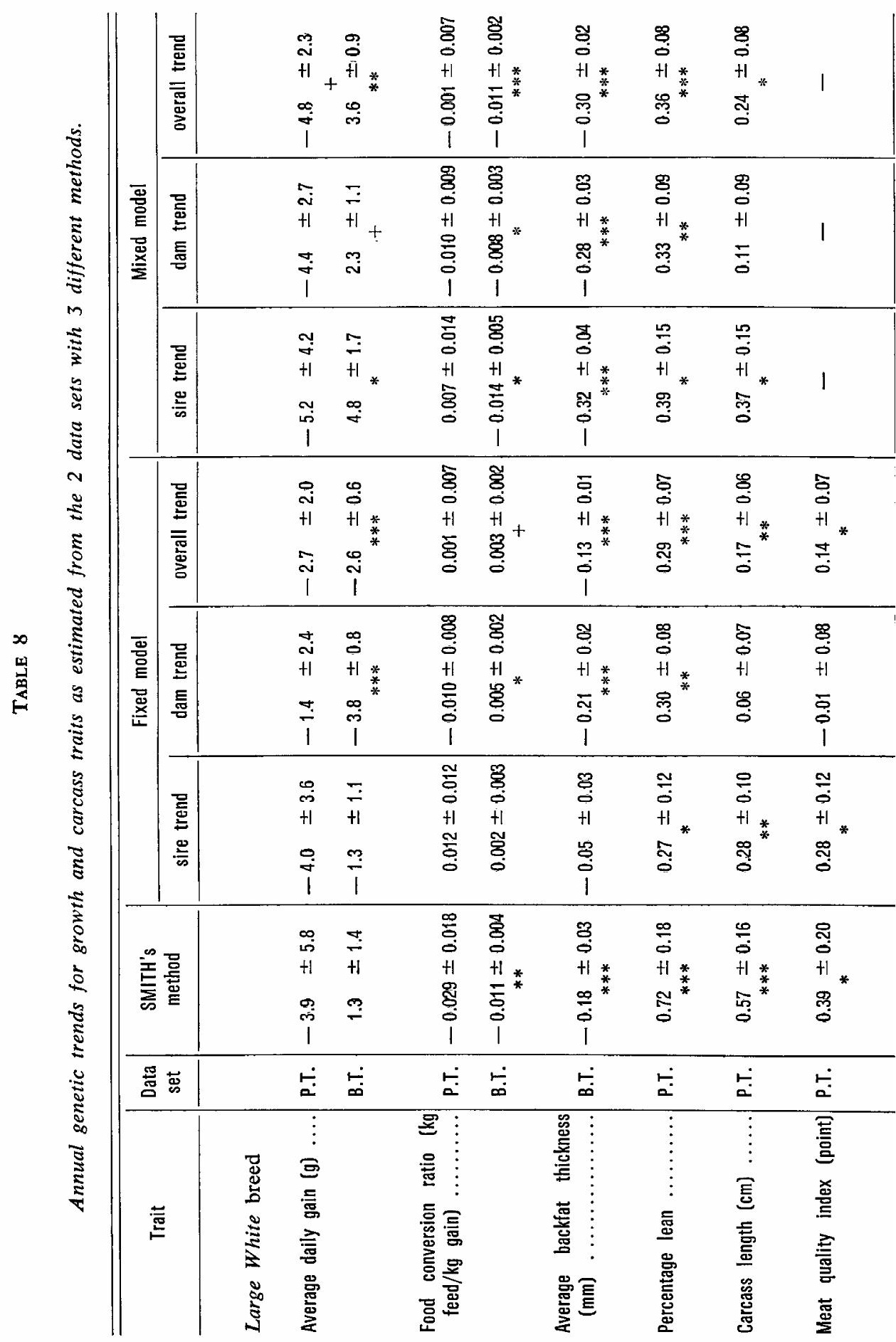




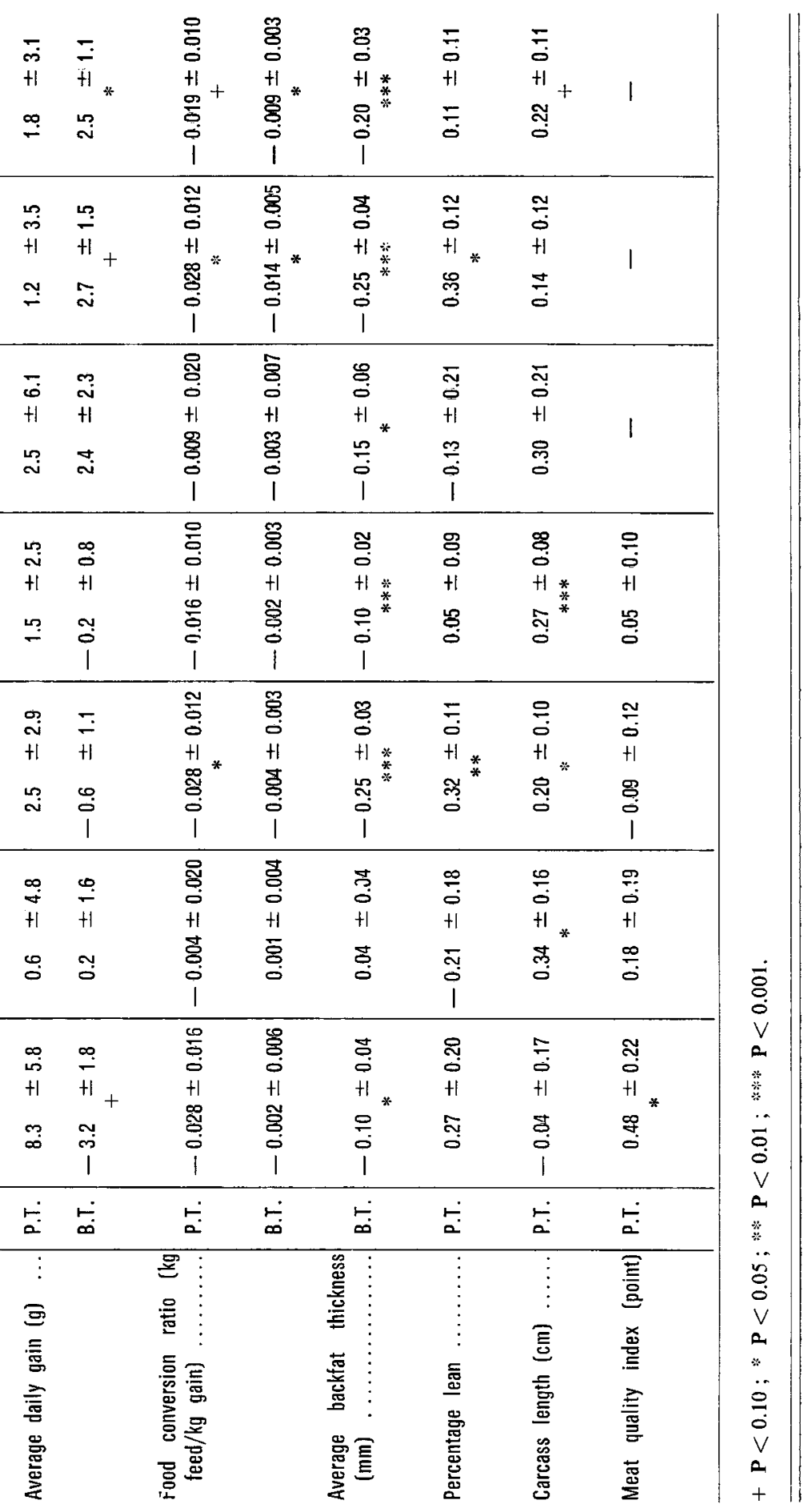


traits (fig. $1 \mathrm{~b}$ ). In the case of average daily gain in the Large White breed, changing heritability from 0.2 to 0.6 increased the estimates of genetic trend by 14 p. 100 in sires and 50 p. 100 in dams, whereas the sampling variance of estimates was much less affected (tabl. 9). Estimates given by the fixed model analysis applied to B.T. data were significantly unfavourable in the Large White and were not significant in the French Landrace breed. The difference between the estimates of cohort effects given by the 2 linear models was increasing from the beginning to the end of the period studied (figures $1 \mathrm{a}$ and $1 \mathrm{~b}$ ).

TABLE 9

Effect of using different values of heritability $\left(h^{2}\right)$ on the mixed model estimates of annual genetic trend (case of average daily gain in the Large White B.T. data set).

\begin{tabular}{l|c|c|c}
\hline \hline \multirow{2}{*}{$\mathrm{h}^{2}$} & \multicolumn{2}{|c}{ Annual genetic trend $(\mathrm{g})$} \\
\cline { 2 - 4 } & sires & dams & overall \\
\hline 0.20 & $4.47 \pm 1.63$ & $1.70 \pm 1.11$ & $3.08 \pm 0.83$ \\
0.44 (n) & $4.84 \pm 1.70$ & $2.30 \pm 1.12$ & $3.57 \pm 0.85$ \\
0.60 & $5.10 \pm 1.72$ & $2.54 \pm 1.12$ & $3.82 \pm 0.86$ \\
\hline
\end{tabular}

(a) Value actually used.

Results obtained with the fixed model analysis appeared to be biased downwards, as expected in the case of a within-cohort selection of sires or dams. This was not observed in the progeny-test data. Similarly, the adjustment for selection of repeated sires in the B.T. data set markedly lowered the estimates of genetic trends given by SMITH's method. Annual genetic change in average daily gain (g) became $1.3 \pm 1.4$ instead of $3.5 \pm 1.3$ in the Large White breed and $-3.2 \pm 1.8$ instead of $1.9 \pm 1.7$ in the French Landrace breed whereas corresponding results for food conversion ratio $(\mathrm{kg}$ feed $/ \mathrm{kg}$ gain) were respectively $-0.011 \pm 0.004$ instead of $-0.020 \pm 0.004$ and $-0.002 \pm 0.006$ instead of $-0.018 \pm 0.005$.

\section{b) Progeny-test clata}

Growth traits measured in P.T. stations showed no significant genetic improvement in the Large White breed. As a matter of fact, the estimated genetic level of sire cohorts followed a strongly unfavourable trend between 1967 and 1973 and has been slightly improving from 1973 to 1980 , for both average daily gain and food conversion ratio (fig. 2 a). First cohorts might be represented by a selected sample of sires having a better apparent genetic value than immediately following cohorts. The similarity of the results given by the mixed model and the fixed model must be noticed. Voluntary food intake in P.T. stations was not analysed with the mixed model procedure : however, results from the fixed model analysis indicated a slightly negative trend which was not significant. 
(0) Large White breed

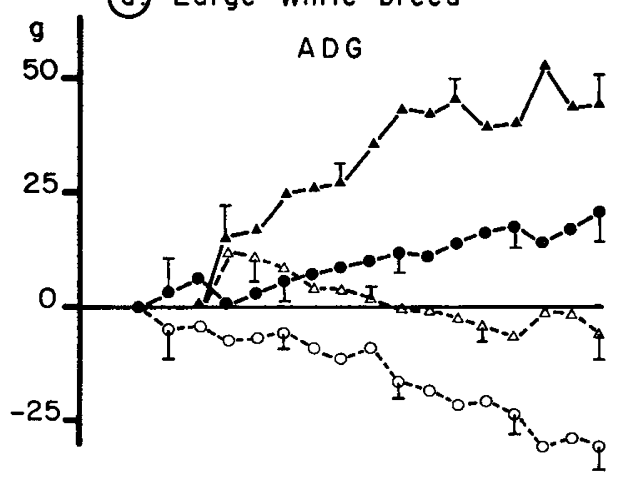

(b) French Landrace breed

$A D G$

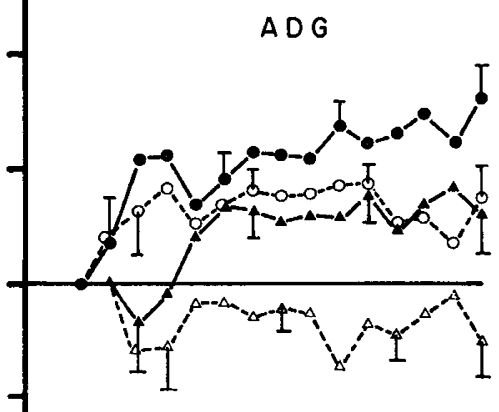

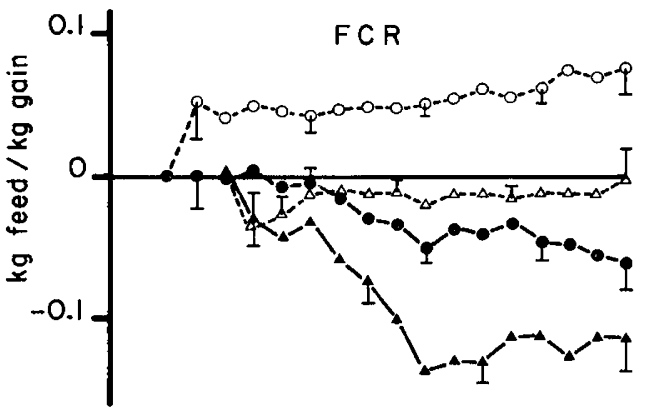
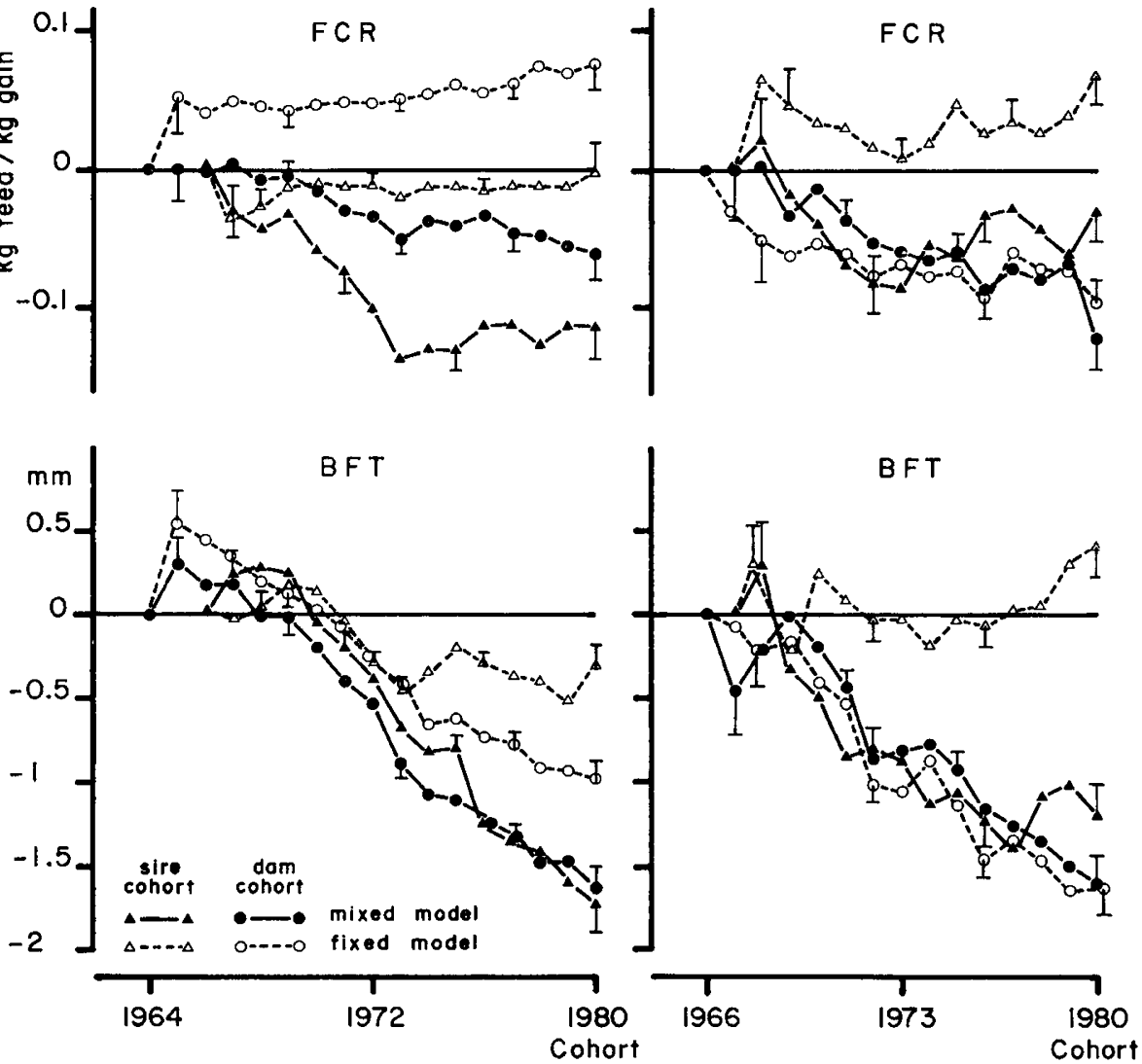

FIG. 1

Trends in sire and dam cohort effects estimated by the fixed model or the mixed model for traits measured in boar performance-test stations (B.T.) : average daily gain (ADG), food conversion ratio (FCR) and average backfat thickness (BFT). 


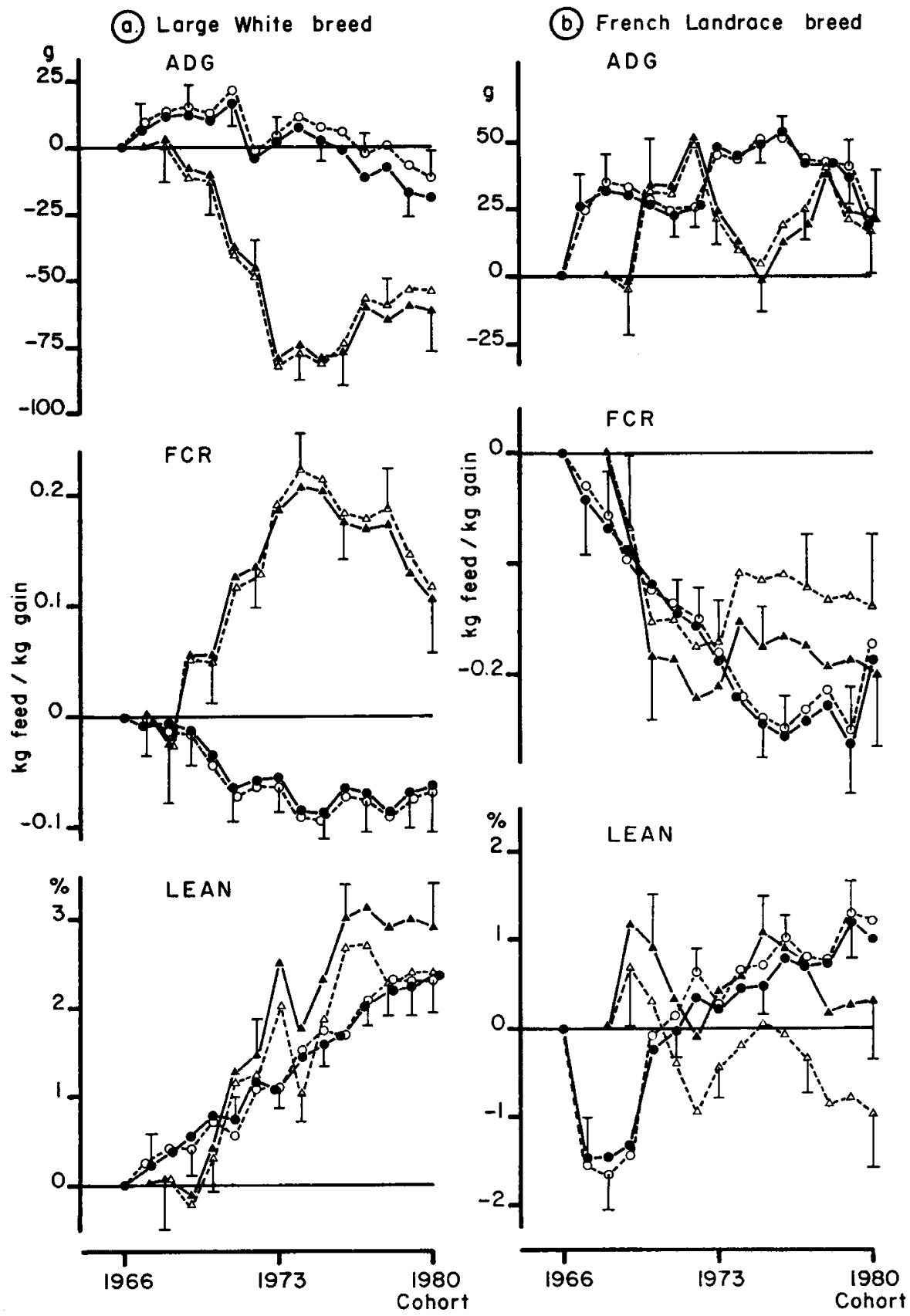

FIG. 2

Trends in sire and dam cohort effects estimated by the fixed model or the mixed model for traits measured in progeny-test stations (P.T.) : average daily gain (ADG), food conversion ratio $(F C R)$ and percentage lean (LEAN). The graphic symbols are the same as in figure 1. 
Estimated genetic trends for growth traits in the French Landrace breed appeared slightly favourable in P.T. data, especially as regards food conversion ratio. Estimated genetic level of sire cohorts for food conversion ratio improved strongly until 1973 and changed very little afterwards (fig. 2 b).

\section{Carcass traits}

Genetic trends were significantly favourable both for lean content (P.T. data) and average backfat thickness (B.T. data) in the Large White breed. The trend of estimated cohort effects was fairly linear, and sire and dam trends were much closer to each other than in the case of growth traits. A strong correlative response to selection occurred for carcass length which increased by about $0.3 \mathrm{~cm}$ per year. Trends were lower in the French Landrace breed : the overall genetic trend in lean content (P.T. data) was not significant owing to an opposition between the sire and dam trends. As regards the meat quality index, a genetic improvement of about $0.17 \pm 0.07$ unit per year was found in the Large White breed. This overall trend was mainly due to the trend in the sire cohorts since no trend at all appeared in the dam cohorts. Trends in the French Landrace breed were not significant with the fixed model analysis but favourable with SMITH's method.

\section{Pooled estimates of genetic trends}

The estimates of genetic trends given by the mixed model and SMITH's method appear to be the least biased. They were considered as being independent and weighted by the reciprocal of their sampling variances to give a combined estimate of genetic trend (tabl. 10).

TABLE 10

Pooled estimates of annual genetic trends $\left(\Delta \mathrm{G}_{\mathfrak{a}} \pm \mathrm{SE}\right)$.

\begin{tabular}{|c|c|c|c|}
\hline Trait & $\begin{array}{c}\text { Data } \\
\text { set }\end{array}$ & Large White breed & French Landrace breed \\
\hline Average daily gain $(\mathrm{g}) \ldots$ & B.T. & $2.9 \pm 0.8$ & $1.0 \pm 1.0$ \\
\hline & P.T. & $-4.7 \pm 2.1$ & $3.2 \pm 2.7$ \\
\hline $\begin{array}{c}\text { Food conversion ratio }(\mathrm{kg} \\
\text { feed } / \mathrm{kg} \text { gain) } \ldots \ldots \ldots\end{array}$ & $\begin{array}{l}\text { B.T. } \\
\text { P.T. }\end{array}$ & $\begin{array}{l}-0.011 \pm 0.002 \\
-0.003 \pm 0.007\end{array}$ & $\begin{array}{l}-0.008 \pm 0.003 \\
-0.022 \pm 0.008\end{array}$ \\
\hline $\begin{array}{c}\text { Average } \text { backfat thickness } \\
(\mathrm{mm})\end{array} \ldots \ldots \ldots \ldots \ldots \ldots$ & B.T. & $-0.26 \pm 0.02$ & $-0.16 \pm 0.02$ \\
\hline Percentage lean...$\ldots \ldots$ & P.T. & $0.42 \pm 0.07$ & $0.15 \pm 0.10$ \\
\hline Carcass length $(\mathrm{cm}) \ldots \ldots$ & P.T. & $0.31 \pm 0.07$ & $0.14 \pm 0.09$ \\
\hline
\end{tabular}




\section{Discussion}

\section{A. Estimation models}

The validity of the results relies on some hypotheses which are to be discussed.

An important source of bias occurs when selection takes place in the data. All methods used assume a random sampling of sires, dams and progeny throughout the period. The breeder may choose the piglets on their own growth performance before the test or may deliver preferential environmental conditions to them. However, the weight and the age at the entrance on test must stay within strict limits imposed by the testing rules. The effect of a possible selection or preferential treatment of piglets before the test is probably low and randomly distributed, and it should not affect the comparisons between cohorts. The choice of the sires and dams of the tested animals is a more critical point when estimating genetic change. No selection was achieved on the records of the progeny-test stations, and results of the different methods were indeed in fairly good agreement with each other for this data set. The boar performance-test records were actually used by the breeders to keep the best sires. This selection on the data submitted to analysis caused the trends derived from the fixed model to be biased downwards. The mixed model and the modified within-sire regression method could only take into account a within-cohort selection of sires on the available data. Bias may also occur if the oldest sires are selected on unobservable data, for instance relatives' performance within the herd. The accuracy of the a priori information that the breeder may obtain is probably low, depending on the size of the herd. A previous selection of the sires of the tested pigs could not be ruled out but its importance could not be evaluated. Some of the results appear difficult to explain, particularly the non-linear trend of sire cohort effects for growth traits in the progeny-test data of the Large White breed. A change in a possible a priori selection of sires or in the sample of herds using the progeny-test could have been responsible for this pattern : indeed, the mixed model and the fixed model gave the same results, both being unable to distinguish the effect of any previous choice of sires.

Preferential matings rely mainly upon the ages of sires and dams since natural mating is mostly used. This source of bias was eliminated in the model including both sire and dam cohorts; it was taken into account in the within-sire regression method under the assumption that the older dams had a lower genetic level and that the genetic trend was the same in sires and dams. If the female mates were chosen on the basis of own or progeny performance, a source of bias remains. However, the accuracy and the intensity of selection of dams within the herd are probably low and this factor was neglected. Older dams are more likely to be kept by the breeders on the basis of reproductive performance. Since production and reproduction traits are generally considered to be genetically independent in the pig (e.g. LEGAULT, 1971 ; MORRIS, 1975), the latter type of selection should not bias the estimates of genetic trends for production traits.

All the methods used fail to take into account the non-genetic effect of the age of dam on progeny performance. Piglets from first parity litters may have a slightly 
lower average daily gain on test than piglets from litters of higher parity (e.g. Standal, 1973 ; Willeke \& Richter, 1979 ; Schneider et al., 1982 ; Lundeheim \& ERIKSSON, 1984). As noticed by the latter authors, it is difficult to remove the effect of genetic trend when estimating the effect of parity. Such an effect could result in a lower estimate of genetic change in dams than in sires for average daily gain. This was indeed observed in the Large White breed for boar performancetest data.

In a population with overlapping generations, a uniform rate of response to selection is only obtained asymptotically in the 2 sexes (HILl, 1974 ; ELSEN \& MocQUOT, 1974). The graphs representing the cohort effects do not show any particular delay in the genetic improvement of dams. The dam trends were most often lower than the sire trends in the Large White breed. However, differences between sire and dam trends were seldom significant, whatever the breed. Wide differences between sire and dam trends were generally found by LUNDEHEIM \& ERIKSSON (1984) who looked for explanations in the estimation model or the age of dam effect. If the latter effect did exist, it would have affected the 2 breeds in the same way : this is not the case in the latter study as well as in our study. As to the estimation model of the present analysis, negative but weak covariances occurred between the estimates of sire and dam cohort effects. However the comparison of sire and dam trends in the same breed is far from showing the same pattern for all the traits of a given data set. This suggests that the estimation model alone cannot be held responsible for the differences between sire and dam trends.

Optimal use of the mixed model methodology requires some additional conditions. Thus, the relationship matrix of sires and dams could not be taken into account. Variance components were estimated on the data obtained in testing stations although variance components should be derived from the population before selection (HENDERSON, 1979). Comparison of the estimates of heritability that were first obtained for progeny-test data recorded between 1953 and 1966 (Ollivier, 1970) to those obtained for the progeny-test data recorded between 1970 and 1978 (Ollivier et al., 1981) did not show any trend toward a decrease of genetic variance as might be expected in response to selection. The sire variance component used in the mixed model analysis might have been slightly over-estimated since it includes the herd component which may partly represent effects of the pre-test environment. This is likely to particularly affect the growth traits. An upward bias in the assumed heritability will lead to over-estimation of the genetic change, without affecting very much the accuracy of the estimate.

The overall genetic trend in sires and dams was the most accurate estimate since its standard error was about 1 p. 100 of the standard deviation for the boar performance-test data and 2 p. 100 for the progeny-test data. This was partly due to the negative covariance between the 2 regression coefficients that were obtained for sire and dam cohorts. The dam trend was more accurately estimated than the sire trend, because of the longer use of dams. The estimate given by the within-sire regression method was generally the least accurate, its standard error being up to twice that of the overall genetic trend (sire + dam). With the same number of tested animals, estimation of genetic trend through the planned use of reference sires or the use of a control line would have been more precise (SMITH, 1977 ; TIXIER \& Ollivier, 1984). 


\section{B. Phenotypic and genetic trends}

\section{Environmental effects}

Phenotypic trends result from both genetic and environmental changes. The genetic trends were generally of the same sign as the phenotypic trends but appeared substantially lower for growth traits.

Possible non-genetic causes of phenotypic change could have been an increase in the concentration of digestible energy in the diet and a reduction in food wastage leading to an improvement in food conversion ratio. A reduction in food wastage might have actually occurred following the use of new self-feeders. An improvement of the average health status of the animals coming from the breeding herds is suggested by the decrease of the elimination rate of boars on test between 1973 and 1978 . A better health status may partly explain the large phenotypic improvement of average daily gain.

The ratio of genetic trend to phenotypic trend was generally of the same magnitude for the traits measured in boar performance-test stations, with slightly higher ratios in the Large White breed. A greater discrepancy was found between genetic and phenotypic trends for the traits measured in progeny-test stations. In particular, a same trait does not show the same pattern in both breeds. As the 2 breeds are tested together in the stations, these differences are more probably due to the low accuracy of the estimates of genetic trends in progeny-test traits.

\section{Estimated genetic change}

The estimates of yearly genetic gains lie generally below 0.5 p. 100 of the mean for growth traits, whereas the estimates of yearly genetic gains in body composition traits lie between 0.3 and 1.7 p. 100 of the mean.

The economic appraisal of the estimated genetic change was derived from the parameters currently used in the French commercial product evaluation programme (ANONYMOUS, 1984); the coefficients are $0.144 \mathrm{FF}$ for $1 \mathrm{~g}$ of average daily gain, - $134 \mathrm{FF}$ for one point of food conversion ratio and $8 \mathrm{FF}$ for one $\mathrm{kg}$ of lean in the carcass with head. From the progeny-test data, the annual genetic trends in the Large White breed correspond to a gain of $2.73 \mathrm{FF}$ in carcass value and to an increase of $0.27 \mathrm{FF}$ in production cost relative to the fattening period, the overall economic gain reaching 2.46 FF per year. However, the analysis of boar performancetest data gives a more favourable evaluation for the production cost which decreases by $1.9 \mathrm{FF} /$ year. The same calculation for the French Landrace breed yields a yearly genetic gain of $4.08 \mathrm{FF}$ according to the results obtained in progeny-test data (i.e. a decrease of $3.36 \mathrm{FF}$ in production cost and an increase of $0.72 \mathrm{FF}$ in carcass value). The decrease in production cost reaches only $1.16 \mathrm{FF}$ according to the analysis of French Landrace boar performance-test data.

As compared to the previous estimates obtained in France from progeny-test data, the yearly genetic change in growth performance seems to have slowed down in the Large White breed since it amounted to around 2.2 p. 100 of the mean between 1953 and 1966 (Ollivier, 1974) and around 1.5 p. 100 between 1965 and 1973 (Hourx et al., 1978). The genetic improvement in lean content in the Large White breed was very low between 1953 and 1966 with a yearly trend of 0.02 percentage 
points, but it became important between 1965 and 1973 with a yearly trend of 0.55 percentage points (HouIx et al., 1978). The positive trend was maintained between 1967 and 1980 with a yearly genetic gain of 0.42 percentage points. The first French studies of genetic change based upon boar performance-test data gave no significant result for the period 1965-1970 (NAveAU, 1971 ; ChEsnaIs, 1973), probably because the number of data was limited and the bias due to the selection of sires was not taken into account.

No previous estimates of genetic trends are available for comparison in the French Landrace breed.

The results may be summarized through the calculation of lean tissue growth rate (LTGR) and lean tissue food conversion (LTFC) as described by FowLER et al. (1976) and formerly applied to the estimation of genetic trend by OLliviER (1980). The results in table 11 were derived from the estimates obtained from the progeny-test records. The genetic trends in LTGR and LTFC are favourable but low in both breeds, since they represent 0.2 and 0.5 p. 100 of the means, respectively.

\section{TABLE 11}

Yearly genetic trends $\Delta G_{a}$ lean tissue growth rate (LTGR) and lean tissue food conversion (LTFC)

estimated from the records of progeny-test stations between 1970 and 1981.

\begin{tabular}{|c|c|c|c|c|}
\hline \multirow{2}{*}{ Breed } & \multicolumn{2}{|c|}{$\operatorname{LTGR}(g / j)$} & \multicolumn{2}{|c|}{ LTFC (kg feed/kg lean) } \\
\hline & mean & $\Delta \mathrm{Ga}$ & mean & $\Delta \mathrm{Ga}$ \\
\hline Large White & 321 & 0.8 & 7.95 & -0.042 \\
\hline French Landrace & 315 & 0.4 & 8.16 & -0.037 \\
\hline
\end{tabular}

\section{Comparison of estimated and expected responses to selection}

The expected response to selection is not easy to calculate in a national population. Genetic improvement arises from several sources, i.e. boar selection in central testing stations, boar and gilt selection on the basis of on-farm testing, immigration of breeding animals, and the criteria may be slightly different in each case. Only the expected response to the boar selection in central testing stations was taken into account to allow the comparison with the estimated genetic trends (tabl. 12). The realized selection intensity is difficult to know and may have changed throughout the period, as well as the generation interval which is only approximately determined. The value of 2.3 years was chosen as an average generation interval and 0.7 standard deviations as an average selection intensity, assuming a selection rate of 20 p. 100 in males and no selection in females. The "direct» responses in traits measured in boar performance-test stations were calculated using the phenotypic and genetic variances and covariances given by TiBAu i Font \& Ollivier (1984), for both Large White and French Landrace breeds. The "correlated $~ r e s p o n s e s$ in progeny-test traits were derived from the genetic correlations estimated between performance-test and progeny-test traits (GuebLeZ, 1982). It is to be noted that the expected genetic trends 
are not known with a great accuracy : the sampling variance of the genetic parameters can be rather high, particularly that of the genetic correlations. It can be noticed that the «correlated » expected response is much lower than the «direct» expected response for average daily gain.

TABLE 12

Comparison of the estimated annual genetic trends with the expected annual responses to the boar selection index used between 1970 and 1980.

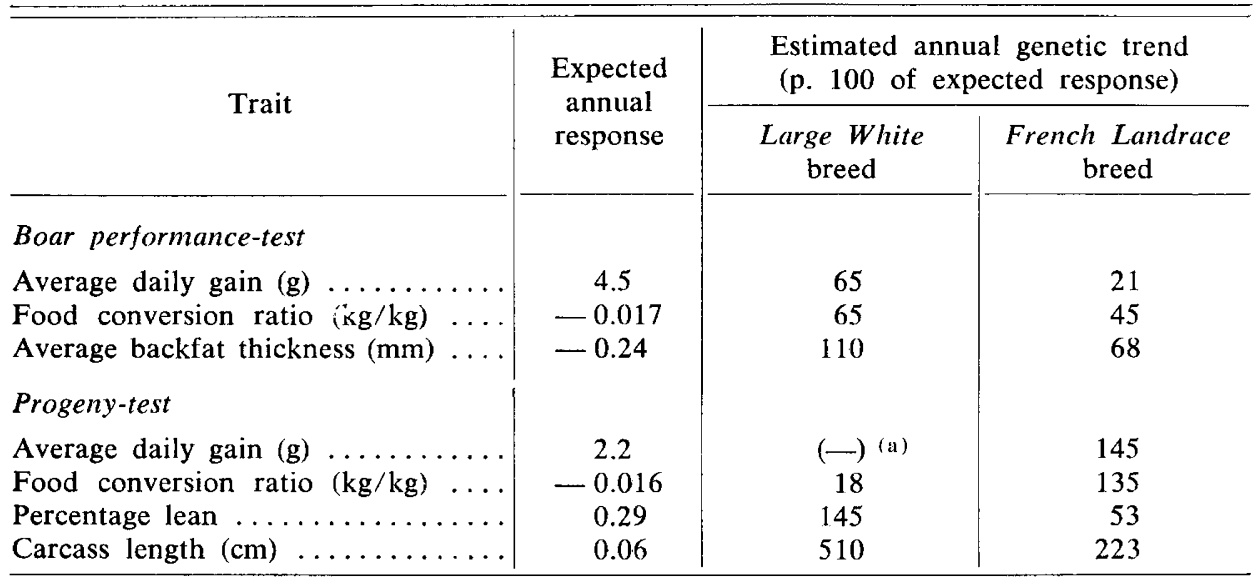

(a) Expected and estimated trends are of opposite sign.

The pooled estimates of genetic trends were expressed as a percentage of the expected responses (tabl. 12). The estimated genetic trends were in agreement with the expected ones since they were of the same sign, except for average daily gain of Large White gilts in progeny-test stations. In both breeds, the ratio of observed over expected responses was rather higher for food conversion ratio than for average daily gain, as well for the «direct» as for the «correlated» responses. As shown by selection experiments, responses in growth rate and feed efficiency are sometimes puzzling. Single-trait selection experiments have generally been quite successful except for food conversion ratio (BERNARd \& FAHMY, 1970 ; JUNGST et al., 1981 ; WeBB \& KING, 1983). Selection experiments on an index including average daily gain and backfat thickness have generally yielded favourable correlated responses in food conversion ratio (SATHER \& Fredeen, 1978 ; Vangen, 1980 ; Ollivier, 1980). But the addition of food conversion ratio to the 2 former traits in the index led to a lowered response in growth rate (e.g. Chadwick \& SMith, 1976 ; Ellis et al., 1979 ; MACPHEE, 1981).

Another particular feature of the present results is the higher ratio of observed to expected responses in carcass traits than in growth traits for the Large White breed. The French Landrace breed shows the same pattern for the "direct 》 responses only. The effective weights given to each of the 3 traits of the boar index might have been different from the expectation. Introduction of foreign breeding animals may 
also have played a role at the beginning of the period studied : 26 p. 100 of the Large White sires having offspring in progeny-test stations during 1969 were born abroad, this proportion reaching 40 p. 100 for the French Landrace breed in 1972. Proportion of foreign sires fell below 5 p. 100 in both breeds after 1978.

Both breeds showed a considerably higher genetic trend in carcass length than expected. This could mean that breeders consider the body length of females to be positively correlated with their reproductive ability and make some selection on this trait.

As far as meat quality is concerned, the expected response to the boar selection index was unfavourable whereas the estimates of SMITH's method and of the fixed model tend to be favourable. Results from selection experiments are contradictory in this respect (e.g. Froystein et al., 1979 ; Standal, 1979 a ; Ollivier et al., 1985).

Finally the observed genetic trends in performance-test traits were in rather good agreement with the expected responses to boar selection in central stations whereas the observed genetic trends in progeny-test traits were sometimes inconsistent.

\section{Foreign results}

Estimation of genetic trends in other countries for the last decade was realized in Great Britain for the Large White and Landrace breeds by the use of a control line (Mitchell et al., 1982), in Norway for the Landrace breed by the use of a control line and by the within-sire regression of progeny performance on time, adjusted for sire selection (STANDal, $1979 \mathrm{~b}$ ) and in Sweden for the Landrace and Yorkshire. breeds by the mixed model procedure (LUNDEHEIM \& ERIKsson, 1984). In those studies, the annual genetic trends were generally favourable and amounted to around $5 \mathrm{~g}$ for average daily gain, $-0.03 \mathrm{~kg}$ feed $/ \mathrm{kg}$ gain for food conversion ratio and $-0.5 \mathrm{~mm}$ for average backfat thickness. Comparisons of genetic gains between countries are difficult to interpret because the testing procedure is not always the same. Our: estimates of genetic trends appear to be generally smaller. Genetic trends were estimated from field records in Nebraska (DAvid et al., 1985) : genetic improvement was low in backfat thickness and reached $0.6 \mathrm{~kg} /$ year in weight at 140 days. Estimation of genetic trends from individual breeding values predicted by the mixed model methodology was achieved for the first time in the pig using on-farm and station records (Hudson \& KENNEDY, 1985). Estimates were favourable (around $-0.1 \mathrm{~mm}$ per year for backfat. thickness).

\section{Conclusions}

The selection achieved in 2 French pig breeds, i.e. Large White and French Landrace, succeeded in the genetic improvement of carcass leanness and to a lesser extent of food conversion ratio and average daily gain. No detrimental response was observed on meat quality traits.

Estimation of genetic trends from records of central stations which are not collected for that purpose encounters major problems : certain sources of bias may be 
present, with little possibility to evaluate them, and a very large amount of data is necessary in order to get accurate estimates. It is to be mentioned that the planned use of frozen semen collected from a sample of A.I. boars born in 1977 will allow estimation of genetic trends achieved between 1977 and 1982 in the Large White and French Landrace breeds. The results of this study will be compared to the present estimates in order to conclude on the effects of pig selection in recent years.

As to the selection objective for next years, a major point is to decide whether the efficiency of lean tissue deposition is economically more important than the rate of lean tissue deposition. The optimal boar performance-test index established by Tibau i Font \& Ollivier (1984) does not give much weight to average daily gain since the expected response per generation and per unit of selection intensity corresponds to 0.07 phenotypic standard deviations for this trait, as compared to 0.37 and 0.44 phenotypic standard deviations for food conversion ratio and weight of backfat, respectively. However, if the non-feeding costs of the fattening period relatively increase, the optimal index would give a slighlty lower weight to food conversion ratio and the expected response in average daily gain would become higher. Furthermore, it may be expected that the decrease in carcass fat content will reach a physiological limit and meat quality will become economically more important in the future.

Received July 16, 1985.

Accepted October 15, 1985.

\section{Acknowledgements}

We are indebted to the staff of central testing stations for collecting the data throughout the period and to the computer processing team for bringing the data sets up to date. We are also very grateful to Nils LUNDEHEIM and Jan-Ake ERIKSSON, Sweden, who kindly provided us with the program for the mixed model analysis, and to Bernard BonAITI and Christian Felgines who made this program compatible with our computer system.

\section{References}

Anonymous, 1984. Résultats du $11^{\text {e }}$ test de contrôle des produits terminaux des schémas de sélection et croisement. Techni-porc, 7 (5), 49-68.

BernaRd C., FaHMY H., 1970. Effect of selection on feed utilization and carcass score in swine. Can. J. Anim. Sci., 50, 575-584.

Chadwick W.C., SMith J.L., 1976. Response to index selection for economy of production and carcass lean content in Large White pigs. Anim. Prod., 22, 164-165 (Abstr.).

CHESNAIS J., 1973. Essai de mesure du progrès génétique réalisé en France en race Large White de 1965 à 1970.14 pp., Mémoire Dép. Génét. Anim. I.N.R.A.

DAVID P.J., Johnson R.K., SochA T.E., 1985. Selection practices and genetic and phenotypic trends estimated from Nebraska SPF swine field records. J. Anim. Sci., 61, 1411-1420. 
F.llis M., Smith W.C., Laird R., 1979. Correlated responses in feed intake to selection for economy of production and carcass lean content in Large White pigs. Anim. Prod., 28, 424 (Abstr.).

Elsen J.M., Mocquot J.C., 1974. Méthode de prévision de l'évolution du niveau génétique d'une population soumise à une opération de sélection et dont les générations se chevauchent. In : Bulletin Technique du Département de Génétique Animale $n^{\circ}$ 17, 30-53, I.N.R.A.

Fowler V.R., Bichard M., Pease A., 1976. Objectives in pig breeding. Anim. Prod., 23, 365-387.

Froystein T., SCHIE K.A., Nostvold S.O., 1979. Halothane sensitivity, blood CPK-values and meat quality characteristics in pigs selected for rate of gain and backfat thickness. Acta Agric. Scand., Suppl. 21, 432-440.

Gueblez R., 1982. Corrélations génétiques entre les mesures faites en station sur les jeunes verrats et les femelles des races Large White et Landrace Français. 13 pp., Rapport de stage, Station de Génétique quantitative et appliquée, I.N.R.A.

Henderson C.R., 1979. Using estimates of variances in predictions of breeding value under a selection model. In : VAN VLeCK L.D., Searle S.R. (ed.), Proceedings of a Conference in honor of C.R. Henderson, Ithaca, July 16-17, 1979, 217-227, Cornell Univ., Ithaca.

HiLl W.G., 1974. Prediction and evaluation of response to selection with overlapping generations. Anim. Prod., 8, 117-139.

Houix Y., Dando P., Sellier P., 1978. Estimation à l'aide d'une lignée-témoin de l'évolution génétique des caractères d'engraissement et de carcasse du porc Large White en France de 1965 à 1973. Ann. Génét. Sél. Anim., 10, 557-568.

Hudson G.F.S., KenNedy B.W., 1985. Genetic trend of growth rate and backfat thickness of swine in Ontario. J. Anim. Sci., 61, 92-97.

Jacquet B., Sellier P., Runavot J.P., Brault D., Houix Y., Perrocheau C., Gogué J., Boulard J., 1984. Prédiction du rendement technologique de la fabrication du « jambon de Paris » à l'aide de mesures prises à l'abattoir. $16^{6}$ Journées de la Recherche porcine en France, Paris, 1-3 février 1984, 49-58, I.T.P., Paris.

Jungst S.B., Christian L.L., Kuhlers D.L., 1981. Response to selection for feed efficiency in individually fed Yorkshire boars. J. Anim. Sci., 53, 323-331.

Legault C., 1971. Corrélations entre les performances d'engraissement et de carcasse et les performances d'élevage chez le porc. Ann. Génét. Sél. Anim., 3, 153-160.

Lundeheim N., Eriksson J.A., 1984. Estimating genetic change in the Swedish pig population by using mixed model methodology (BLUP). Acta Agric. Scand., 34, 97-106.

MacPhee C.P., 1981. Selection for efficient lean growth in a pig herd. Aust. J. Agric. Res., 32, 681-690.

Mitchell G., Smith C., Makower M., Bird P.J.W.N., 1982. An economic appraisal of pig improvement in Great Britain. 1-Genetic and production aspects. Anim. Prod., 35, 215-224.

Morris C.A., 1975. Genetic relationships of reproduction with growth and with carcass traits in British pigs. Anim. Prod., 20, 31-44.

Naveau J., 1971. Le progrès génétique dans les troupeaux de sélection de 1966 à 1970 . Bull. Inst. Tech. du Porc, 1971/3, 13-16.

Ollivier L., 1970. L'épreuve de la descendance chez le porc Large White français de 1953 à 1966. I. Analyse de la variation. Ann. Génét. Sél. Anim., 2, 311-324.

Ollivier L., 1974. L'épreuve de la descendance chez le porc Large White franşais de 1953 à 1966. III. Progrès génétique. Ann. Génét. Sél. Anim., 6, 477-492.

Ollivier L., 1980. Estimated responses to eleven years of boar selection. Livest. Prod. Sci., 7, 57-66.

Ollivier L., Derrien A., Molénat M., 1980. Paramètres génétiques des verrats Large White et Landrace Français soumis au contrôle individuel de 1969 à 1978. Analyse préliminaire. Techni-porc, 3 (1), 7-12. 
Ollivier L., Derrien A., Molénat M., 1981. Paramètres génétiques des femelles Large White et Landrace Françatis du contrôle de descendance sur la période 1970-1978. $13^{e}$ Journées de la Recherche Porcine en France, Paris, 4-5 février 1981, 293-298, I.T.P., Paris.

Ollivier L., Gruand J., Felgines C., 1985. Evolutions observées dans l'expérience de sélection porcine de Rouillé (1965-1984). 17 Journées de la Recherche Porcine en

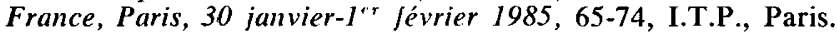

Pommeret P., Naveau J., 1979. Composition anatomique de la carcasse : la découpe parisienne normalisée (D.P.N.). Institut Technique du Porc, Centre Expérimental de Sélection Porcine de Maxent, rapport 79-06, 14 pages ronéotypées.

Sather A.P., Fredeen H.T., 1978. Effect of selection for lean growth rate upon feed utilization by the market hog. Can. J. Anim. Sci., 58, 285-289.

Schneider J.F., Christian L.L., KuhI.ERs D.L., 1982. Effects of season, parity and sex on performance of purebred and crossbred swine. J. Anim. Sci., 54, 728-738.

Sмітн C., 1962. Estimation of genetic change in farm livestock using field records. Anim. Prod., 4, 239-251.

SMith C., 1977. Use of stored frozen semen and embryos to measure genetic trends in farm livestock. Z. Tierzïchtg. Zï̈htgsbiol., 94, 119-127.

Standal N., 1973. Studies on breeding and selection schemes in pigs. III. The effect of parity and litter size on the "on-the-farm» testing results. Acta Agric. Scand., 23, 225-231.

Standal N., 1979 a. Selection for low backfat and high growth rate and vice-versa for 9 generations : effect on quantity and quality of lean meat. Acta Agric. Scand., Suppl. 21, 117-121.

Standal N., 1979 b. Genetic change in the Norwegian Landrace pig population. Acta Agric. Scand., 29, 139-144.

Syrstad O., 1966. Studies on dairy herd records. III. Estimation of genetic change. Acta Agric. Scand., 16, 3-14.

Tibau i Font J., Ollivier L., 1984. La sélection en station chez le porc. Bull. tech. Dép. Génét. Anim. n" 37, I.N.R.A.

TIXIER Michèle, 1984. Evolution génétique des performances de croissance et de carcasse dans trois races porcines françaises. $122 \mathrm{pp}$., Thèse de $3^{\circ}$ cycle, Université de Paris XIOrsay.

Tixier Michèle, Ollivier L., 1984. Intérêt de l'insémination artificielle pour la mesure du progrès génétique. Séminaire des départements de génétique et physiologie animales de l'I.N.R.A., Toulouse-Auzeville, 23-24 novembre 1983, Insémination artificielle et amélioration génétique : bilan et perspectives critiques, Les Colloques de l'I.N.R.A., $n^{\circ} 29,209-227$.

VANGEN O., 1980. Studies on a two trait selection experiment in pigs. III. Correlated responses in daily feed intake, feed conversion and carcass traits. Acta Agric. Scand., 30, $125-141$

WebB A.J., KING J.W.B., 1983. Selection for improved food conversion ratio in ad libitum group feeding in pigs. Anim. Prod., 37, 375-385.

Willeke H., Richter I., 1979. The effect of parity and litter size on the "on-the-farm» performance tested gilts. Z. Tierzüchtg. Züchtgsbiol., 96, 38-43. 


\section{Appendix A}

SYRSTAD (1966) considered the regression coefficient, B, of performance of later progeny $\left(D_{t}\right.$ in the year $\left.t\right)$ on that of first progeny $\left(D_{1}\right.$ in the first year), $D_{t}$ and $D_{1}$ being both expressed as deviations from contemporary means. Without any genetic change we have :

$$
\mathrm{D}_{\mathrm{t}}=\mathrm{B} \mathrm{D}_{1} \text {. }
$$

If a genetic change takes place in the population at an annual rate $\Delta G_{a}$, then :

$$
\mathrm{D}_{\mathrm{t}}=\mathrm{B} \mathrm{D}_{1}-0.5(\mathrm{t}-1) \Delta \mathrm{G}_{\mathrm{u}}
$$

since there are $(t-1)$ intervals between the years 1 and $t$. Derivation of the regression coefficient of $D_{t}$ on time comes to the following expression :

$$
\mathrm{bD}_{\mathrm{t} \cdot \mathrm{t}}=-0.5 \Delta \mathrm{G}_{\mathrm{a}}-6(1-\mathrm{B}) \mathrm{D}_{1} /[\mathrm{n}(\mathrm{n}+1)]
$$

where $n$ is the number of years of use of the repeated sire $(t=1, \ldots, n)$. The estimate of annual genetic trend is :

$$
\Delta \mathrm{G}_{\mathrm{a}}=-2\left\{\mathrm{bD}_{\mathrm{t} \cdot \mathrm{t}}+6(1-\mathrm{B}) \mathrm{D}_{1} /[\mathrm{n}(\mathrm{n}+1)]\right\} .
$$

If the repeated sire is randomly chosen, $D_{1}$ is expected to be zero and the estimate of $\Delta G_{a}$ is unbiased, but this is not any longer the case when the first progeny of the repeated sire are above (or below) the contemporary average.

In the B.T. data, $D_{1}$ was taken as the average performance of all progeny tested during the first 6-month-period of use of the sire. B was estimated by the regression coefficient of average performance of later progeny on that of first progeny for all the repeated sires. Values of $\mathrm{B}$ were in the Large White and the French Landrace breed respectively 0.204 and 0.179 for average daily gain, 0.157 and 0.193 for food conversion ratio and 0.281 and 0.360 for average backfat thickness, with standard errors in the range of 0.034 to 0.056 .

An approximate correction factor was calculated as follows :

$$
\mathrm{C}=\sum_{\mathrm{i}=1}^{\mathrm{N}}\left\{6 \mathrm{D}_{1 \mathrm{i}} /\left[\mathrm{n}_{\mathrm{i}}\left(\mathrm{n}_{\mathrm{i}}+1\right)\right]\right\} / \mathrm{N}
$$

where $\mathrm{N}$ is the number of repeated sires. Let $\mathrm{f}=(1-\mathrm{B}) \mathrm{C}$. The estimate of annual genetic trend adjusted for selection of repeated sires was obtained from the average within-sire regression coefficient $b^{\prime}$ :

$$
\Delta \mathrm{G}_{n}=-4\left(\mathrm{~b}^{\prime}+\mathrm{f}\right)
$$

where the 6-month-period is taken as the unit of time.

The regression $x$ of age of dam on age of sire is also to be considered and the final expression is :

$$
\Delta \mathrm{G}_{\mathrm{a}}=-4\left(\mathrm{~b}^{\prime}+\mathrm{f}\right) /(1+\mathrm{x})
$$

As $\mathrm{B}$ and $\mathrm{C}$ were estimated from our data, their sampling variances were taken into account to calculate the approximate standard error of the estimate of $\Delta G_{a}$. 


\section{Appendix B}

The variances and covariances of the constant estimates of cohort effects were extracted from the inverse of the incidence matrix after absorption of dam and sire effects. Let $\mathbf{V}$ be the submatrix corresponding to sire cohorts, $\mathbf{W}$ the submatrix for dam cohorts and $\mathbf{T}$ the submatrix of covariances between sire and dam cohort effects. The linear regression model of the constant estimates for sire cohorts $(\hat{\mathbf{g}})$ or dam cohorts ( $\hat{\mathbf{f}})$ on cohort number was :

$$
\begin{aligned}
\hat{\mathbf{g}} & =\mathbf{X}_{1} \mu_{1}+\beta_{1} \mathbf{G}+\mathbf{e}_{1} ; \\
\text { and } \hat{\mathbf{f}} & =\mathbf{X}_{2} \mu_{2}+\beta_{2} \mathbf{F}+\mathbf{e}_{2} ;
\end{aligned}
$$

where $\ell_{1}\left(\right.$ resp. $\left.\ell_{1_{2}}\right)=\mathrm{a}$ constant,

$\mathbf{X}_{1}$ (resp. $\left.\mathbf{X}_{2}\right)=$ a column vector of 1's with as many rows as elements of $\hat{\mathbf{g}}$ (resp. $\hat{\mathbf{f}}$ ),

$\beta_{1}$ (resp. $\beta_{2}$ ) = linear regression coefficient of the estimates for sire (resp. dam) cohort effect on cohort number,

$\mathbf{G}$ (resp. F) = a column vector of sire cohort's numbers (resp. dam cohort's numbers),

$\mathbf{e}_{1}$ (resp. $\left.\mathbf{e}_{2}\right)=$ a vector of random errors with zero mean and

$\operatorname{Var}\left(\mathbf{e}_{1}\right)=\mathbf{V}_{\sigma_{\mathrm{e}}}{ }^{2}$ (resp. $\left.\mathbf{W} \sigma_{\mathrm{e}}^{2}\right), \mathbf{V}_{\sigma_{\mathrm{e}}}^{2}$ being the residual variance of the linear model of estimation of the cohort effects.

Let $\mathbf{Q}_{1}=\mathbf{I}-\mathbf{X}_{1}\left(\mathbf{X}_{1}^{\prime} \mathbf{V}^{-1} \mathbf{X}_{1}\right)^{-1} \mathbf{X}_{1} \mathbf{V}-1$

and $\mathbf{Q}_{2}=\mathbf{I}-\mathbf{X}_{2}\left(\mathbf{X}_{2}^{\prime}, \mathbf{W}^{-1} \mathbf{X}_{2}\right)^{-1} \mathbf{X}_{2} \mathbf{W}^{-1}$

with I being the identity matrix. The generalized least-squares estimators of the regression coefficients $\beta_{1}$ and $\beta_{2}$ are :

$$
\begin{aligned}
& \quad \hat{\beta}_{1}=\left[\mathbf{G}^{\prime} \mathbf{V}^{-1} \mathbf{Q}_{1} \mathbf{G}\right]^{-1} \mathbf{G}^{\prime} \mathbf{V}^{-1} \mathbf{Q}_{1} \hat{\mathbf{g}} \\
& \text { and } \hat{\beta}_{22}=\left[\mathbf{F}^{\prime} \mathbf{W}^{-1} \mathbf{Q}_{2} \mathbf{F}\right]^{-1} \mathbf{F}^{\prime} \mathbf{W}^{-1} \mathbf{Q}_{2} \hat{\mathbf{f}} \\
& \text { with } \operatorname{Cov}\left(\hat{\beta}_{1}, \hat{\beta}_{2}\right)=\left[\mathbf{G}^{\prime} \mathbf{V}^{-1} \mathbf{Q}_{1} \mathbf{G}\right]^{-1} \mathbf{G}^{\prime} \mathbf{V}^{-1} \mathbf{Q}_{1} \mathbf{T} \mathbf{Q}_{2} \mathbf{W}-1 \mathbf{F}\left[\mathbf{F}^{\prime} \mathbf{W}^{-1} \mathbf{Q}_{2} \mathbf{F}\right]^{-1}
\end{aligned}
$$

Three estimates of genetic trends were obtained :

$$
\begin{aligned}
& \widehat{\Delta G}_{a 1}=2 \hat{\beta}_{1} \\
& \Delta \widehat{G}_{a 2}=2 \hat{\beta}_{2} \\
& \Delta \widehat{G}_{a}=\hat{\beta}_{1}+\hat{\beta}_{2}
\end{aligned}
$$

Omitting the $\mathbf{V}$ and $\mathbf{W}$ matrix would have led to under-estimation of the sampling variance of $\hat{\beta}_{1}$ and $\hat{\beta}_{2}$. 